\title{
Analysis of strengthening the practical teaching reform for higher vocational accounting posts
}

\author{
Zhao Chunrong
}

Qinhuangdao Institute of Technology, Hebei Qinhuangdao 066100, China

Keywords: higher vocational education; accounting posts; practical teaching; reform; suggestion

\section{Abstract:}

in recent years, with the rapid development of the times and economic modernization, the demand of modernized talent market for talent gradually tends to the comprehensive quality talent combining operation type with skill type, then the current college talent training has put forward new goals. For higher vocational accounting post teaching, it should make good practical teaching, cultivating a large number of operation type high-quality professional talents for modernization of talent market. In this article, strengthening the practical teaching reform for higher vocational accounting post is analyzed. Firstly, the necessity of strengthening the practical teaching reform for higher vocational accounting post is analyzed, then the main problems existing in the practical teaching of higher vocational accounting post are analyzed, finally, some suggestions for the practical teaching reform for higher vocational accounting post is proposed.

In twenty-first century, along with the gradual deepening of reform and opening up, modernization higher vocational colleges also face the reform in different degree [1-4], for the practical teaching of accounting posts, it should pay more attention to the cultivation of students' practical ability, and focus on a comprehensive combination study of theory and practice [5-8]. Nowadays, although the intensity of the practical teaching of higher vocational accounting post is increased, practical teaching efforts still have defects, how to do a good job in teaching reform of higher vocational accounting training has always been one of the hot research of accounting professional field of various higher vocational colleges[9,10]. Therefore this paper has certain economic value and practical significance to the analysis of practical teaching reform in higher vocation accounting post.

\section{The necessity of strengthening practical teaching of higher vocational accounting post}

in current talent market, the demands of accounting professional talents are more and more, to strengthen practical teaching of accounting post often have a certain need, mainly has the following several points:

A Promote the effective integration of accounting theory knowledge and practical knowledge

Currently, accounting specialty students in vocational colleges practice off campus, mainly choose some enterprises and institutions of the relevant financial sector as the main base, but due to the limited reason of the working environment and commercial secrets, the actual accounting practice is only a form, it is difficult to integrate into the relevant accounting theory in practice. Therefore, to strengthen practical teaching of accounting post, the main is to ensure that students be personally on the scene, more to digest the theory knowledge, master skills, and promote the effective integration of theory and practice.

B Help students to make a reasonable occupation career planning

Strengthening practical teaching, not only deepened the student to grasp the theoretical 
knowledge, but also cultivate the ability of students to the basic operation of accounting practice, which lays a solid foundation for the students future employment, ensuring that students have a more reasonable occupation career planning.

C Stimulate the students' interest and creative thinking in accounting learning

in the actual teaching process, accounting job training courses pay more attention to the authenticity and practice of the curriculum content, by means of the relatively new teaching method, the main characteristics of the training activities can be realized as more as possible, then to effective excite the accounting students' interest in learning, which has certain positive role to cultivate the creative thinking and the innovation ability of accounting students at this stage, ensuring that students learn the full comprehension of interest in accounting.

\section{Problems existing in practical teaching of higher vocational accounting post}

There exist all kinds of problems in practical teaching of higher vocational accounting post, which are represented as follows:

\section{A The teaching goal and the course design and lack of reasonable positioning}

Although the accounting job training course in each accounting majors of higher vocational colleges are equipped, in the actual teaching, still it follows the thought of focusing theory teaching and avoiding practice teaching, still lacks of relatively perfect teaching system. In the course design, the lack of a reasonable position of practice teaching target is difficult to really play the essence of practice teaching.

The most prominent contradiction in the current accounting talent market is, the contradiction between human unit's demands and supply of accounting personnel, this contradiction and conflict is not in quantity, but the structural contradictions. The demand of social for financial staff, has changed from the business accounting to management type, which is the high quality and pioneering compound talent. At present, the accounting personnel consistent with the requirements are not many, therefore, the phenomenon of unpopular graduates emerges in accounting personnel market. Talent demands are inclined to the practical experience of the supplier, the social much needed to under marketing and knowledge management, and can quickly adapt to the work of the accounting personnel. This is also from the side reflects the fact that the comprehensive ability in vocational college accounting graduates is not strong, knowledge is too narrow, hands-on ability is poor.

B Class time of practical teaching is less

Practical teaching class is relatively small, which is one of the main problems existing in the practical teaching of higher vocational accounting job. Due to the lack of practice teaching, students' practical ability is relatively poor, so it is difficult to lay a solid foundation for future employment, seriously affecting the students' learning initiative. Because the purpose of accounting practice teaching lacks of the systematic understanding, many practical teaching of higher vocational colleges accounting job is only confined to the accounting skill practice, it is often a transplant of economic business enterprise, asking students to practice accounting, accounts and accounting statements, which leads to the students as simple as carrying machine in practice. The students' knowledge cultivated in this way is too narrow, lacks of systematic understanding of accounting work, and basic to the development of high level financial management talents. Due to the lag teaching hardware in a number of schools, cause that the students' practice ability cannot to have the real exercise and improve in school, which affects the quality of teaching and the teaching effectiveness of accounting post training. 


\section{The course lacks of normative, teaching methods outdates}

In the training teaching process of accounting job, it has relative single accounting subject. In the actual teaching process, the involved industry is relatively small, and the training content does not fully reflect the comprehensive. For accounting treatment steps and the original documents of the rational knowledge, there are some of the attention, but the understanding of training posts is not clear, the quality of training material is relatively low, leading to serious effects on the thinking ability of students, having certain restriction for the students' innovation spirit. At present, the accounting post training in some higher vocational colleges still remains in the manual stage. Today, in the rapid development of science and technology, the accounting information processing technology has got great development, a lot of traditional cost accounting and financial accounting works have been computerized, therefore, the new situation requires the accounting staff should not only master the professional knowledge, but also must be able to operate a computer, to master the use of methods of computer in the accounting work.

$D$ The teaching organization lacks of flexibility

The teaching process of accounting job training, tends to focus on teachers' inspection guidance, and has no real operation training on students, lacking of accounting voucher transfer simulation operation, and the spirit of unity and cooperation and to develop team spirit, also have certain defects, in which ignores the students' space feeling in the real work, and accounting occupation moral education. In order to let the students comprehensively understand accounting skills, some institutions in accounting job training, make every student fully embracing the general ledger, ledger, journal register and report the editing work, accounting and cashier work, all done by one person, this approach is not consistent with the actual accounting work, and not conducive to the students to understand on the internal control system, more do not talk to go up the accounting system of experience. Therefore, in this way, students are certainly out of touch with reality, so that when go to work they cannot adapt to the work quickly.

\section{The idea of strengthening the training teaching reform of higher vocational accounting post}

The training teaching reform of higher vocational accounting job should take ability as the standard, take the student as the main body, around the needs of accounting job, to continue to expand teaching content, reform teaching methods, improve the software and hardware conditions of the practice teaching, strengthen teaching management, improve the evaluation mechanism, to establish a scientific and reasonable teaching system, to cultivate the actual operation ability of the students engaged in accounting work.

A Take ability as the standard, to expand the contents of training teaching of accounting job

The use of training materials in the economic and business data, should not be entirely to the teachers' subjective concoct, it should originate from the enterprise actual economic business. Through the teacher's processing, poor representative and special economic business are eliminated, to ensure that the articulation between the data before and after is correct, only this can be as training data. In this way, it can ensure that the practicability, pertinence and simulation of the contents of accounting practice teaching. At the same time, all kinds of vouchers, books and statements used in the training process, but also to the extent possible, consistent with the actual enterprise and the choice of economic business, which is convenient for students to the practice operation.

$B$ Take the students as the main body to reform teaching method

In the practice teaching of accounting, it should adhere to the principle of that students are as the 
main body, the working process is orientation, reforming the traditional teaching method, and according to the different requirements of skills training, take a variety of teaching methods.

First of all, the teaching organization should take the group as the unit, using the simulation environment and the role simulation design of learning process. The implementation of division of job rotation system, let each student in the treating process of economic and business data, have different roles (such as accounting supervisor, general ledger, cashier, documentation, a storekeeper, etc.), and stimulate students' learning enthusiasm. Teachers in the teaching process, can widely use case analysis, discussion teaching, situational teaching, answering questions and heuristic teaching methods, drawing inferences about other cases from one instance, so that making students in the base to obtain perceptual knowledge, to understand the theory knowledge used by the actual operation, train students' ability to use accounting information and solve practical problems.

Secondly, in the way of teaching, teachers should make full use of modern educational technology, give full play to multimedia technology, and make integration of text, images, sound, video and other information, to make teaching more intuitive, effectively improving the quality of teaching. At the same time, on the basis of the student completing manual operation, from the original voucher input, vouchers preparation, the book registration to the accounting statements generated, using computer data processing advantage, to simulate accounting computerization, and true reproduce the actual operation of the enterprise accounting. So, it can not only test the accuracy of student manual preparation of data, and make the teaching more close to reality, to shorten the adaptation period students after graduation work. In addition, it can also make full use of network technology, to upload the teaching materials to the Internet, extend the teaching activity to outside, and make teachers and students communication better.

$C$ Center on the needs of practical teaching, improve the software and hardware condition of accounting practice teaching

In order to improve the practice teaching quality, the higher vocational colleges should constantly improve the teaching conditions of manual simulation training room and computerization training room. From the training room management, data preparation, financial software to the training room layout, it should be closed to the actual business, and strive to have high emulation, for group discussion and sub post operation, let the students have the feeling of be personally on the scene, bring them into their own role as soon as possible, to create a good atmosphere of occupation.

At the same time, the higher vocational colleges should strengthen the construction of double qualified teacher's team, increase the professional accounting teacher and the ratio of the teacher has enterprise work experience. In addition, schools should arrange young teachers to the enterprise to practice, and accumulate practical work experience, improving practical teaching ability. At the same time, a large number of specialized personnel and skilled craftsmen can be employed from enterprises to the school as part-time teachers, gradually forming the mechanism of in training skills course, practical teaching is mainly composed by part-time teachers with high level skills or double teachers, to stimulate students interest in accounting training courses, and improve the effect of accounting practice teaching.

\section{Thinking about practical teaching reform of higher vocational accounting post}

At the present stage, in the practical teaching process of higher vocational accounting post, high quality training should be do well for professional accounting. At the same time, the direction of the teaching reform, should make the needs of accounting professional skill as the starting point, to make practical teaching reform of accounting post, servicing for the modernization of the talent 
market. For the main problems existing in the current training teaching of higher vocational accounting job, and combined with the demand of market for accounting professional talent, this paper put forward some suggestions as follows:

\section{A Make reasonable orientation of curriculum design, and increase the training class}

in training teaching reform of higher vocational accounting job, it should fully play the advantages of practical teaching of accounting post, give full play to practice this profession technology curriculum of higher vocational accounting job training, improve the teaching importance, and make it as a specialized branch curriculum. According to the actual conditions of the school, 2 hours per week will be to 4 hours or 6 hours. At the same time, schools also need to reform the curriculum assessment methods, do a good job in the practice operation skill examination, and make the student achievement into student's credits.

\section{$B$ Optimize the content of accounting job training}

In the process of optimizing the content of accounting job training, it will broaden the scope of accounting post training, to ensure the training subject involving multiple industries. The training content needs to break the traditional over reliance on manufacturing, as far as possible relate to some accounting knowledge in commercial, hotel and real estate and logistics enterprises, ensuring students' future diversified employment options. At the same time, it also needs to significantly improve the training data level, to do a good job in basic accounting auditing teaching, and combined with the internal control of accounting and financial analysis, comprehensively improve the students' ability of creative thinking, culture the ability to analysis problem, solve the problem of, and to comprehensively strengthen the moral education of accounting occupation, providing both ability and political integrity personnel for modern accounting industry.

\section{$C$ Innovation of organization mode and teaching means of accounting post training}

Innovation of organization mode and teaching means of accounting post training needs to ensure that the methods of accounting job training have a certain diversity and pertinence. By means of grouping training way, following the rational enterprise management, and simulating the occupation role of accounting, to determine accountant and cashier position and so on. Through regular job rotation form, ensure every student to take on different job tasks and responsibilities, to ensure the students to master the various positions of the working content and working procedure, exercising the student unity cooperation ability. In the process of teaching, by means of modern information technology, the manual simulation operation and modern computerized related operations are made organic combination to some extent. With the help of software system, set on a variety of economic and business, to comprehensive cultivate students' willpower, independent working ability and the occupation judgment ability.

D Strengthen the teacher construction of accounting training

To strengthen the practical teaching reform of higher vocational accounting post, it is necessary to strengthen the teacher construction of accounting training, and to create the double-quality teachers. Combined with the actual situation of higher vocational colleges, the school should make the regular training for accounting teachers, to rich the teachers' practical experience, and ensure that teachers have professional skills and qualities. On the one hand, the accounting teachers are sent to different business to make part-time or exercise, and then gradually increase the experience of accounting teachers. On the other hand, the school can employ the specialists with rich practical experience and senior accountant, to carry out the comprehensive training for teachers in higher vocational colleges, and do a good guidance of students' practical teaching. At the same time, the school can regularly held some seminars, to strengthen communication between teachers, and discuss the difficulty and key work of targeted. Finally, in fact, accounting training teachers should 
search relevant training opportunities through independent form, and improve the comprehensive ability of themselves, fully mobilized the enthusiasm of the teaching, and complete the basic work of practice teaching.

To make a long story short, strengthen the teaching reform of higher vocational accounting job training, also want to reasonable teaching appraisal way to search for, pay attention to the teacher training courses, and pay more attention to students' training course examination, to practice learning of students' comprehensive ability training, to ensure that students have a comprehensive development.

\section{Conclusion}

At the present stage, the practical teaching reform of higher vocational accounting job, pay more attention to the cultivation of students' practice operation ability, combined with a theoretical knowledge to do practical teaching. however, the practical teaching reform of higher vocational accounting post should strengthen accounting training infrastructure investment, construct doublequality teachers, to train students' practical ability, cultivate students' innovative thinking and creativity, provide high-quality and professional accounting talents for the modernization of the talent market, speed up the reform process of modernization of higher vocational education, and promote the rapid development of China's modernization of the national economy.

\section{Acknowledgement}

The subject name is the practical teaching of higher vocational education in accounting research, the paper indicate that is education science "twelfth five-year" plan in 2011 in hebei province project project (project number: 11050177)

\section{References}

[1] Yang Jianping. Professional teaching reform of computerized accounting in higher vocational education colleges in southwest -- taking Chongqing vocational technical institute of Industry and Trade Polytechnic as a case [J]. Journal of Chongqing vocational technical institute of Industry and Trade Polytechnic, 2009, 02:15-40.

[2] Yang Xinhui. On the reform of accounting practice teaching the in higher vocational college [J]. Economic research guide, 2012, (29): 279-280.

[3]Chen Jincui. Exploration of accounting practice teaching and reform in higher education school [J]. Journal of Changchun Institute of education, 2012, 28 (9): 110-111.

[4] Wang Xingjun, Wang Shuping, Guan Fengxia. Exploration of the teaching reform of accounting specialty course docking comprehensive training in vocational colleges [J]. Business economics, 2010, 09:114-115.

[5] Yang Zheqi. The training model of practical methods and skills for accounting major in higher vocational colleges [J]. Journal of Zhejiang Industry and Trade Vocational College, 2010, 03:47-51.

[6] Wang Binyan. Discussion on accounting practical teaching in higher vocational colleges [J]. Journal of Taiyuan University, 2012, 13 (1): 115-117.

[7] Guo Yanping. Exploration of accounting manual practical teaching reform of "Post vocational skill type" in high vocational colleges [J]. The age of science, 2011, (3): 187-187188.

[8] Feng Ping. The comprehensive training teaching reform of accounting post [J]. Technology horizon, 2012, 07:81-82. 
[9] Xu Yanqing. To strengthen the accounting practice teaching to improve students' employment competence [J]. Chinese Science Innovation Herald, 2011, 11:187-188.

[10] Chen Hanlong. New ideas of perfecting the teaching system of higher vocational accounting training [J]. Journal of Fujian Normal University (Fuqing campus), 2013, 01:97-100. 